\title{
The implications of product modularisation on the development process, supplier integration and supply chain design in collaborative product development
}

\author{
Koppenhagen, F. ${ }^{a}$, Held, T. $^{\mathrm{a},{ }^{*}}$ \\ ${ }^{\mathrm{a}}$ Hamburg University of Applied Sciences, Department of Mechanical Engineering and Production Management, Germany
}

\section{A B S T R A C T}

Generating economies of scale is one of the most desirable goals when developing modular product systems. Since complex products are commonly developed in collaboration between an Original Equipment Manufacturer (OEM) and its suppliers, pursuing this goal inherently establishes interdependencies between the development process, supplier integration and supply chain design. To fully reap the benefits of modular product systems requires a comprehensive approach that encompasses these fields and addresses the interdependencies between them via a coherent collaboration between development and purchasing. This is the main focus of this work. In this paper, we first describe how the product development process has to be restructured for the concerted development of modules and overall products within the scope of a modular product system. Secondly, we propose a new collaboration model between the OEM and its suppliers, since OEMs need to collaborate directly with suppliers of lower levels of the value chain in order to facilitate the standardisation of components and modules across different products. Finally, we delineate an awarding process for both development services and production volumes for series supply that resolves the conflicting priorities of economies of scale and avoiding over-dependence on single suppliers. The process models described in this paper have been conceived based on systems engineering principles and have been successfully tested and further refined throughout several industrial projects carried out with two automotive manufacturers. The resulting approach will be demonstrated using a generic example taken from the automotive industry.
\end{abstract}

\section{ARTICLE INFO}

Keywords:

Supply chain design;

Robust value chains;

Modularity;

Product development;

Complexity management;

Awarding process;

Supplier integration;

Automotive industry

*Corresponding author:

tobias.held@haw-hamburg.de

(Held, T.)

Article history:

Received 14 August 2020

Revised 28 January 2021

Accepted 7 March 2021

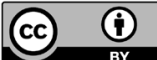

Content from this work may be used under the terms of the Creative Commons Attribution 4.0 International Licence (CC BY 4.0). Any further distribution of this work must maintain attribution to the author(s) and the title of the work, journal citation and DOI.

\section{References}

[1] Ulrich, K.T., Eppinger, S.D., Yang, M.C. (2020). Product design and development, Seventh edition, McGraw-Hill, New York, USA.

[2] Eitelwein, O. (2009). Modular architectures in firms and value systems: Antecedents, structures, performance impact, Stiftung Wiss. Hochschule f. Unternehmensführung, Vallendar, Germany.

[3] Göpfert, J. (2013). Modulare Produktentwicklung: Zur gemeinsamen Gestaltung von Technik und Organisation, Wiesbaden, Gabler, Norderstedt, Germany.

[4] Wagner, H. (1999). Modularisierung von neuronalen Netzen, Doctoral dissertation, Technischen Fakultät der Universität Bielefeld, Bielefeld, Germany, https://d-nb.info/957576080/34.

[5] Maier, M.W., Rechtin, E. (2009). The art of systems architecting, Third edition, CRC Press, Boca Raton, Florida, USA.

[6] Haberfellner, R., de Weck, O., Fricke, E., Vössner, S. (2019). Systems engineering, Fundamentals and applications, Springer Nature, Cham, Switzerland, doi: 10.1007/978-3-030-13431-0.

[7] Simon, H.A. (1962). The architecture of complexity, In: Proceedings of the American Philosophical Society, Vol. 106, No. 6, 467-482. 
[8] Simon, H.A. (1973). The organization of complex systems, In: Pattee, H.H. (ed.), Hierarchy theory: The challenge of complex systems, G. Braziller, New York, USA, 1-27.

[9] Koppenhagen, F. (2004). Systematische Ableitung modularer Produktarchitekturen - Komplexitätsreduzierung in der Konzeptphase, Shaker Verlag, Aachen, Germany.

[10] Skirde, H. (2015). Kostenorientierte Bewertung modularer Produktarchitekturen, Josef Eul Verlag GmbH, Lohmar, Germany.

[11] Mikkola, J.H. (2007). Management of product architecture modularity for mass customization: Modeling and theoretical considerations, IEEE Transactions on Engineering Management, Vol. 54, No. 1, 57-69, doi: 10.1109/ TEM.2006.889067.

[12] Foroughi, K. (2014). Gestaltung eines Vorgehensmodells zur Umsetzung von Lean Development entlang der Supply Chain, Otto-von-Guericke-Univ., Inst. für Logistik und Materialflusstechnikf per Borsch, Magdeburg, Germany.

[13] Zirpoli, F., Becker, M.C. (2011). The limits of design and engineering outsourcing: Performance integration and the unfulfilled promises of modularity, R\&D Management, Vol. 41, No. 1, 21-43, doi: 10.1111/i.1467-9310.2010. 00629.x.

[14] Morgan, J.M., Liker, J.K. (2006). The Toyota product development system, Integrating people, process, and technology, First edition, Productivity Press, Boca Raton, USA, doi: 10.4324/9781482293746.

[15] Daim, T.U., Oliver, T., Phaal, R. (2018). Technology roadmapping, World Scientific Publishing, New Jersey, USA, doi: $10.1142 / 9789813235342$.

[16] Koppenhagen, F. (2011). Verzahnte Produktentwicklung - Wirksames Komplexitätsmanagement durch die kohärente Gestaltung von Produktarchitektur, Entwicklungsorganisation und Entwicklungsprozess, Industrie Management, Vol. 27, No. 5, 13-16.

[17] Koppenhagen, F. (2014). Modulare Produktarchitekturen - Komplexitätsmanagement in der frühen Phase der Produktentwicklung, In: Schoeneberg, K.-P. (ed.), Komplexitätsmanagement in Unternehmen - Herausforderungen im Umgang mit Dynamik, Unsicherheit und Komplexität meistern, Springer, Wiesbaden, Germany, 113-162, doi: 10.1007/978-3-658-01284-7 7.

[18] Imai, K.-I., Nonaka, I., Takeuchi, H. (1985). Managing the new product development process: How Japanese companies learn and unlearn, In: Hayes, R., Clark, K., Lorenz, C. (eds), The Uneasy Alliance: Managing the ProductivityTechnology Dilemma, Harvard Business School Press, Boston, USA, 337-375.

[19] Asanuma, B. (1985). The contractual framework for parts supply in the Japanese automobile industry, Japanese Economic Studies, Vol. 13, No. 4, 54-78, doi: 10.2753/JES1097-203X130454.

[20] Clark, K.B. (1989). Project scope and project performance: The effect of parts strategy and supplier involvement on product development, Management Science, Vol. 35, No. 10, 1247-1263, doi: 10.1287/mnsc.35.10.1247.

[21] Hartley, J.L., Meredith, J.R., McCutcheon, D., Kamath, E.R. (1997). Suppliers' contributions to product development: an exploratory study, IEEE Transactions on Engineering Management, Vol. 44, No. 3, 258-267, doi: 10.1109 /17.618077.

[22] Laseter, T.M., Ramdas, K. (2002). Product types and supplier roles in product development: an exploratory analysis, IEEE Transactions on Engineering Management, Vol. 49, No. 2, 107-118, doi: 10.1109/TEM.2002.1010879.

[23] Danese, P., Filippini, R. (2010). Modularity and the impact on new product development time performance: Investigating the moderating effects of supplier involvement and interfunctional integration, International Journal of Operations \& Production Management, Vol. 30, No. 11, 1191-1209, doi: 10.1108/01443571011087387.

[24] Pereira, R., Ro, Y.K., Liker, J.K. (2014). Product development and failures in learning from best practices in U.S. auto: A supplier perspective, IEEE Transactions on Engineering Management, Vol. 61, No. 3, 545-556, doi: 10.1109/TEM.2014.2323060.

[25] Held, T. (2015). Supplier involvement in product development: A literature review covering three decades of research, In: Proceedings of the 24th Annual International Purchasing and Supply Education and Research Association Conference, Amsterdam, Netherlands, 48-57.

[26] Johnsen, T.E. (2009). Supplier involvement in new product development and innovation: Taking stock and looking to the future, Journal of Purchasing and Supply Management, Vol. 15, No. 3, 187-197, doi: 10.1016/i.pursup. 2009.03.008.

[27] Pandremenos, J., Paralikas, H., Salonitis, K., Chryssolouris, G. (2009). Modularity concepts for the automotive industry: A critical review, CIRP Journal of Manufacturing, Science and Technology, Vol. 1, No. 3, 148-152, doi: 10.1016/j.cirpj.2008.09.012.

[28] Becker, M., Zirpoli, F. (2008). Beyond product architecture: Addressing the challenges of complex product development, In: Proceedings of 25th Druid Conference, Copenhagen, Denmark, 39 pages.

[29] Zirpoli, F., Camuffo, A. (2009). Product architecture, inter-firm vertical coordination and knowledge partitioning in the auto industry, European Management Review, Vol. 6, No. 4, 250-264, doi: 10.1057/emr.2009.25.

[30] Wolters, H. (1995). Modul und Systembeschaffung in der Automobilindustrie: Gestaltung der Kooperation zwischen europäischen Hersteller - und Zulieferunternehmen, Gabler, Wiesbaden, Germany.

[31] Hackenberg, U., Hirtreiter, K., Rummerl, C. (1997). Entwicklungs- und Produktionssynergien der Baukastensystematik, In: ATZ - Automobiltechnische Zeitschrift, Sonderausgabe „Der neue Audi A6“, Vol. 99, No. 3, 48-57.

[32] Huber, G., Kuonath, K. (1997). Das Modulkonzept der Mercedes-Benz A-Klasse, In: VDI-Berichte, 1343, Neue Wege in der Fahrzeugentwicklung, VDI, Düsseldorf, Germany, 21-33.

[33] Fixson, S.K., Ro, Y., Liker, J.K. (2005). Modularisation and outsourcing: Who drives whom? A study of generational sequences in the US automotive cockpit industry, International Journal of Automotive Technology and Management, Vol. 5, No. 2, 166-183, doi: 10.1504/I]ATM.2005.007181.

[34] Henderson, R.M., Clark, K.B. (1990). Architectural innovation: The reconfiguration of existing product technologies and the failure of established firms, Administrative Science Quarterly, Vol. 35, No. 1, 9-30, doi: 10.2307/ 2393549. 
[35] Brusoni, S., Prencipe, A. (2001). Unpacking the black box of modularity: Technologies, products and organizations, Industrial and Corporate Change, Vol. 10, No. 1, 179-205, doi: 10.1093/icc/10.1.179.

[36] Takeishi, A. (2002). Knowledge partitioning in the interfirm division of labor: The case of automotive product development, Organization Science, Vol. 13, No. 3, 321-338, doi: 10.1287/orsc.13.3.321.2779.

[37] Lee, J., Veloso, F.M. (2008). Interfirm innovation under uncertainty: Empirical evidence for strategic knowledge partitioning, Journal of Product Innovation Management, Vol. 25, No. 5, 418-435, doi: 10.1111/j.1540-5885. 2008.00312.x.

[38] Stephan, M., Pfaffmann, E., Sanchez, R. (2008). Modularity in cooperative product development: The case of the MCC 'smart' car," International Journal of Technology Management, Vol. 42, No. 4, 439-458, doi: 10.1504/IJTM. 2008.019385.

[39] Takeishi, A., Fujimoto, T. (2003). Modularisation in the car industry: Interlinked multiple hierarchies of product, production and supplier systems, In: Prencipe, A., Davies, A., Hobday, M. (eds), The business of systems integration, Oxford University Press, Oxford, United Kingdom, 254-278, doi: 10.1093/0199263221.003.0013.

[40] MacDuffie, J.P. (2008). Technological and organizational barriers to modularity: Persistent integrality in the global automotive industry, Mimeo, Wharton, Philadelphia, USA.

[41] Morgan, J.M., Liker, J.K. (2018). Designing the future: How Ford, Toyota, and other world-class organizations use lean product development to drive innovation and transform their business, McGraw-Hill Education, New York, USA.

[42] Fourcade, F., Midler, C. (2005). The role of $1^{\text {st }}$ tier suppliers in automotive product modularization: The search for a coherent strategy, International Journal of Automotive Technology and Management, Vol. 5, No. 2, 164-165, doi: 10.1504/IJATM.2005.007180.

[43] Schaede, U. (2010). Globalisation and the reorganization of Japan's auto parts industry, International Journal of Automotive Technology and Management, Vol. 10, No. 2-3, 270-288, doi: 10.1504/IJATM.2010.032628.

[44] Morgan, J.M. (2002). High performance product development: A systems approach to learn product development process, Ph.D. dissertation, University of Michigan, Michigan, USA, http://hdl.handle.net/2027.42/132677.

[45] Ward, A.C., Liker, J.K., Christiano, J.J., Sobek II, D.K. (1995). The second Toyota paradox: How delaying decisions can make better cars faster, Sloan Management Review 36 (3), 43-61 (Spring 1995), Long Range Planning, Vol. 28, No. 4, 129, doi: 10.1016/0024-6301(95)94310-u.

[46] Liker, J.K., Sobek, D.K., Ward, A.C., Cristiano, J.J. (1996). Involving suppliers in product development in the United States and Japan: Evidence for set-based concurrent engineering, IEEE Transactions on Engineering Management, Vol. 43, No. 2, 165-178, doi: 10.1109/17.509982.

[47] Kersten, W., Koppenhagen, F., Meyer, C. (2004). Strategisches Komplexitätsmanagement durch Modularisierung in der Produktentwicklung In: Spath, D. (ed.), Forschungs- und Technologiemanagement: Potenziale nutzen - Zukunft gestalten, Carl Hanser, München, Germany, 211-218. 


\section{APEM}

\title{
Implikacije modularizacije izdelka na razvojni proces, integracijo dobaviteljev in oblikovanje dobavne verige pri sodelovalnem razvoju izdelkov
}

\author{
Koppenhagen, F. ${ }^{a}$, Held, $\mathrm{T}^{\mathrm{a}}{ }^{, *}$ \\ aHamburg University of Applied Sciences, Department of Mechanical Engineering and Production Management, Germany
}

\begin{abstract}
POVZETEK
Ustvarjanje ekonomije obsega je eden najbolj zaželenih ciljev pri razvoju modularnih proizvodnih sistemov. Ker se kompleksni izdelki običajno razvijajo $\mathrm{v}$ sodelovanju med proizvajalcem originalne opreme (OEM) in njegovimi dobavitelji, zasledovanje tega cilja samo po sebi vzpostavlja soodvisnosti med razvojnim procesom, integracijo dobaviteljev in oblikovanjem dobavne verige. Da bi v celoti izkoristili prednosti modularnih proizvodnih sistemov, je potreben celovit pristop, ki zajema ta področja in obravnava medsebojne odvisnosti med njimi prek skladnega sodelovanja med razvojem in nabavo. To je glavni poudarek tega prispevka. V prispevku najprej opišemo, kako je treba prestrukturirati proces razvoja izdelka za usklajen razvoj modulov in celotnega izdelka v okviru modularnega sistema. Nato predlagamo nov model sodelovanja med proizvajalcem originalne opreme in njegovimi dobavitelji, saj morajo proizvajalci originalne opreme neposredno sodelovati z dobavitelji nižjih ravni vrednostne verige, da bi olajšali standardizacijo komponent in modulov v različnih izdelkih. Nazadnje opisujemo postopek nagrajevanja, tako za razvojne storitve, kot za obseg proizvodnje, za serijsko dobavo, ki rešuje nasprotujoče si prednostne naloge ekonomije obsega in preprečuje preveliko odvisnost od posameznih dobaviteljev. Modeli procesov, opisani v tem članku so bili zasnovani na principih sistemskega inženiringa in so bili uspešno preizkušeni in dodatno izpopolnjeni v več industrijskih projektih, izvedenih $\mathrm{z}$ dvema proizvajalcema avtomobilov. Razviti pristop je prikazan na splošnem primeru iz avtomobilske industrije.
\end{abstract}

\section{PODATKI O ČLANKU}

Ključne besede:

Oblikovanje dobavne verige;

Robustne vrednostne verige;

Modularnost;

Razvoj izdelka;

Upravljanje kompleksnosti;

Postopek nagrajevanja;

Integracija dobaviteljev;

Avtomobilska industrija

*Kontaktna oseba:

tobias.held@haw-hamburg.de (Held, T.)

Zgodovina članka:

Prejet 14. avgusta 2020

Popravljen 28. januarja 2021

Sprejet 7. marca 2021

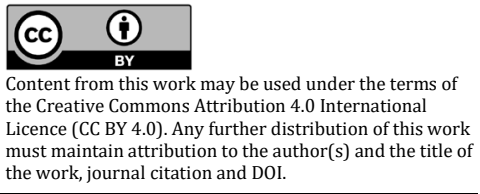

